\title{
Kan Tolkien se wêreld in Afrikaans verbeel(d) word?
}

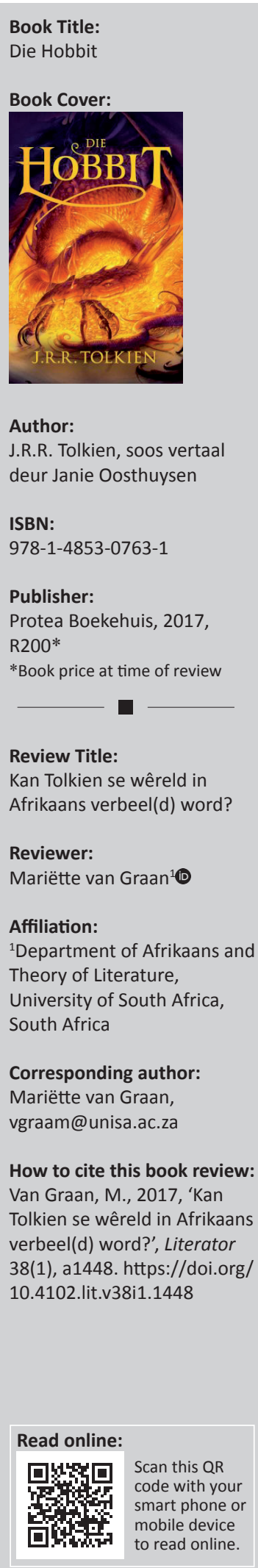

In 'n gat in die grond woon die hobbit, Bilbo Baalens. Op aansporing van Ghandalf die towenaar vergesel hy 13 dwerge op 'n gevaarlike avontuur. Hulle reis na die Eensame Berg om die dwerge se goud van die draak, Smaug, terug te steel. Hulle word gevang deur trolle, aardgeeste en boselwe. Hulle vind skuiling by die elf Elrond, by die vel-veranderaar Beorn, en by die mense van Meerdorp. Wanneer die draak oplaas verslaan is, moet hulle boonop die 'Slag van die Vyf Leërs' oorleef. 'n Avontuur, inderdaad. The Hobbit van J.R.R. Tolkien is nie net 'n geliefde kinderboek nie, maar ook 'n boek wat steeds akademies ondersoek word en ook 'n boek met 'n kultusaanhang. Gevolglik is Oosthuysen se vertaling onvermydelik blootgestel aan moontlike kritiek uit verskeie oorde.

In die geheel is Die Hobbit'n lekker leesboek, maar daar is steurende aspekte aan die vertaling. Die naamgewing is oneweredig. Van die drie trolle word Tom en Bert behou, maar William/Bill word Wieljam/Wiele. Sommige name (soos die van die dwerge) is behou, maar ander is verafrikaans met die verandering of byvoeging van enkele letters (Gollum/Ghollum). Beskrywende name is meestal direk vertaal (Oakenshield/Eikenskild). Plek- en eiename word op dieselfde wyses hanteer. Hierdie oneweredigheid doen nie afbreuk aan die vertaling in die geheel nie, en in die meeste gevalle kom die keuses logies voor. ' $n$ Groter probleem is egter die benaming van spesies in Tolkien se magiese wêreld.

'n Hobbit, Tolkien se skepping, kan 'n hobbit bly in Afrikaans. Dwerge, elwe, feë, trolle en towenaars is gevestig in Afrikaanse kinderstories. Voorbeelde van waar Oosthuysen se benamings egter verkeerd loop, is die Lake-men/Meermense (wat onwillekeurig die meermin oproep) en the First Men of the North wat Noormanne word ('n term wat verwys na die historiese Vikings, van hierdie aarde, nie die menslike spesie in Tolkien se fantasiewêreld nie). Die taaiste taaltameletjie is goblins, wat 'n groot rol speel in Die Hobbit. Hierdie magiese kreature figureer nie sterk in Afrikaanse kinderstories of folklore nie. Woordeboekvertalings vir goblin sluit in 'spook', 'kabouter, 'aardgees' en 'aardmannetjie'. Kenners van die ou Europese folklore en sprokies (waaruit heelwat Afrikaanse kinderstories oorgeneem is, en waaruit Tolkien beslis geput het) sal dadelik die probleem sien: nie een van hierdie genoemde vertalings verwys na dieselfde kreatuur nie; 'n spook en 'n kabouter is nie dieselfde ding nie. Oosthuysen gebruik 'aardgees' vir goblin en 'aardmannetjie' vir hobgoblin. Alhoewel dit tegnies korrek is, het 'aardgees' net nie dieselfde impak nie. Dit roep die beeld op van 'n onstoflike wese, dalk 'n vriendelike gees (iets soos 'n bosfee of boomgees) wat uit die goeie aarde kom. Die probleem word goed geillustreer wanneer Beorn 'n aardgees doodmaak en sy kop op 'n paal sit - hoe dood jy 'n gees, hoe sit jy 'n gees se kop op 'n paal? Tolkien se goblins is liggaamlik lelike, weersinwekkende karakters; alhoewel hulle in die diep aarde (grotte) woon, is hulle boos. Oosthuysen se vertaalde beskrywings is akkuraat, maar die benaming is nie geslaagd nie. Hier is dalk 'n geleentheid vir nuutskepping verpas.

Nog 'n taai stuk vertaalwerk is gesetel in die verskillende dialekte wat hierdie verskillende spesies en karakters praat, maar Oosthuysen het dit goed hanteer. Die trolle se allermins ordentlike taal word 'n platter, growwe, nie-normatiewe Afrikaans: 'Hou jou bek! ... Of dink jy mense gaan vi' ewig hie' stop net lat jy en Bert hulle kan opvreet?' (bl. 50). Ghollum se ekstra '-insess' en 'sssss' word funksioneel oorgedra met ekstra s'e en -es'e: 'Wat isssss hy, my sssssskat? ... Wat het hy in sy handses?' (bl .92). Daar is egter plekke waar die taalgebruik in alledaagse gesprekke tussen hoofkarakters effens te formeel oorkom.

Rympies, raaisels en liedjies vorm 'n groot deel van Tolkien se vertelling en karakterisering. Bilbo en Ghollum se raaisels is baie akkuraat vertaal, maar die vertalings van die liedjies is soms lomp. Daar word heelwat veranderinge (omruiling van versreëls, veranderinge in strofes) gemaak,

Copyright: (C) 2017. The Authors. Licensee: AOSIS. This work is licensed under the Creative Commons Attribution License. 
waarskynlik ter wille van ritme en rym. Meestal is hierdie veranderinge geslaagd, maar sommiges wyk té ver af van die bronteks. Soms word funksionele beeldspraak vervang met rymelary - byvoorbeeld die reël 'Here am I, naughty little fly' in Bilbo se terglied aan die spinnekoppe wat vervang word met 'Aai spaai, joehoe joegaai' (bl .191). In die dwerge se eerste lied oor Bilbo se kombuis-opruiming (bl. 24) sing hulle 'skeur die lap en skop die kat' vir 'cut the cloth and tread on the fat', wat die dwerge as wreed laat voorkom, eerder as die grapmakers wat hulle in daardie toneel is. Dwerge se liefde vir goud is een van hulle kerneienskappe, maar wanneer hulle daaroor sing en 'the heart is bold that looks on gold / the dwarves no more shall suffer wrong' vertaal word met 'die hart is koud wat droom van goud / die dwerge vrees geen daad of perk' (bl. 304), word daar aan die persepsie van dwerge verander.

'n Mens moet die hoed afhaal vir enige vertaler wat 'n werk van hierdie omvang, kompleksiteit en kultusstatus aandurf. In die geheel het Oosthuysen daarin geslaag om die avontuurverhaal met hobbits, dwerge, towenaars, elwe en drake in Afrikaans te verbeel(d). Jong en ontspanningslesers sal ongetwyfeld Die Hobbit geniet. Dit is ook 'n lekker boek om aan die kleiner kinders voor te lees - dit is immers, in die eerste plek, 'n kinderboek. Die meer akademiese lesers en die kultusaanhangers sal waarskynlik meer krities teenoor hierdie vertaling staan. 